\title{
EXOGENOUS EXPENSES IN INDUSTRIES WITH VERTICAL PRODUCT DIFFERENTIATION AND QUALITY CONSTRAINTS
}

\section{Georgi Burlakov}

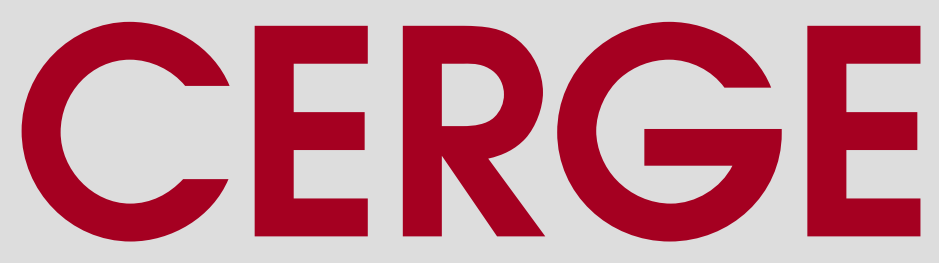

Charles University

Centerfor Economic Research and Graduate Education

Academy of Sciences of the Czech Republic

Economics Institute 


\section{Working Paper Series (ISSN 1211-3298)}

\section{Exogenous Expenses in Industries with Vertical Product Differentiation and Quality Constraints}

Georgi Burlakov

CERGE-EI

Prague, February 2015 
ISBN 978-80-7343-335-2 (Univerzita Karlova. Centrum pro ekonomický výzkum a doktorské studium)

ISBN 978-80-7344-327-6 (Akademie věd České republiky. Národohospodářský ústav) 


\title{
Exogenous Expenses in Industries with Vertical Product Differentiation and Quality Constraints*
}

\author{
Georgi Burlakov ${ }^{\dagger}$ \\ CERGE-EI ${ }^{\ddagger}$
}

\begin{abstract}
In this paper we study how an exogenous expense of owning a market good affects the equilibrium outcome in a market with vertical product differentiation i.e. consumers differ by income but have identical preferences for the good's quality. We identify three possible subgame-perfect equilibrium outcomes dependent on the amount of the exogenous expense. First, at a small exogenous expense tending to zero, quality choice is characterized by maximal product differentiation and all consumers buy one of the two qualities in the market. Second, at a medium exogenous expense, some low-income consumers refrain from buying which incentivizes the producer of the low-quality good to minimize its difference from the high-quality good. In turn, it chooses the best quality from its individually constrained set of quality choices. Third, at a large exogenous expense at which the consumers of the low-quality good cannot afford it, the market is monopolized by the high-quality firm.
\end{abstract}

\begin{abstract}
Abstrakt
Předkládaná stat' se zabývá problematikou výše exogenního výdaje na tržní statek a jeho dopadu na rovnovážný výstup v odvětví při vertikální produktové diferenciaci; tedy za předpokladu, že se spotřebitelé liší z hlediska př́ijmu, ale mají identické preference z hlediska kvality. Na základě naší analýzy identifikujeme tři možné dokonalé rovnováhy podher, závislé na výši exogenního výdaje. Zaprvé, při nízkém výdaji blížícímu se nule je výběr kvality charakterizován maximální diferenciací produktu, přičemž všichni spotřebitelé nakupují jednu $\mathrm{z}$ dostupných kvalit na trhu. Zadruhé, v případě středně vysokého exogenního výdaje se někteří z nízkopříjmových spotřebitelů zdrží nákupu, což motivuje výrobce statku s nízkou kvalitou, aby minimalizoval rozdíl vůči statku s vysokou kvalitou, a tím pádem vybrat nejvyšší kvalitu z množiny všech jemu dostupných kvalit. Konečně, v případě vysokého výdaje, při němž spotřebitelé statku s nízkou kvalitou nejsou již schopni statek nakupovat, dochází k monopolizaci trhu firmou produkující vysokou kvalitu.
\end{abstract}

Keywords: vertical product differentiation, commodity taxation, market participation

JEL classification: L11, L13, L15

\footnotetext{
*I would like to thank Levent Çelik, Randall Filer, Vahagn Jerbashian, Jan Kmenta, Michael Kunin, Ilir Maçi, Fabio Michelucci, Avner Shaked, Jakub Steiner, John Sutton, Sherzod Tashpulatov, Krešimir Žigić (in alphabetic order) for valuable comments and helpful suggestions. All errors remaining in this text are the responsibility of the author.

$\dagger$ georgi.burlakov@cerge-ei.cz

¥CERGE-EI is a joint workplace of the Center for Economic Research and Graduate Education, Charles University in Prague, and the Economics Institute of the Academy of Sciences of the Czech Republic. Address: CERGE-EI, Politickych veznu 7, Prague 11121, Czech Republic.
} 


\section{Introduction}

In industrial organization theory, markets in which consumers differ by income ${ }^{1}$ but have the same preferences for the distinct qualities of the offered goods are defined as vertically differentiated markets. A standard outcome of the solutions of the models of vertical product differentiation is that the structure (respecting the number of firms) and the coveredness ${ }^{2}$ of the market at equilibrium do not depend on the quality differences between goods. Instead, they are fully determined by the length of the support interval of the distribution of the consumer incomes. Particularly, Shaked and Sutton (1982) prove that to have a covered duopoly market at equilibrium, it is necessary and sufficient for consumer income to be uniformly distributed on a support with right bound which is more than twice and less than four times bigger than its left bound. The duopoly result (i.e. with finite equilibrium number of entrants) holds even for the case of free entry; that is when sunk cost is assumed to tend to zero.

In this paper, we propose a stylized model of a vertically differentiated market where consumers face an exogenous expense of owning the good purchased in the market. The aim is to show that in the new setting the structure and the coveredness of the market also depend on the amount of the exogenous expense defined in terms of the equilibrium qualities.

In the real world there are a number of industries that satisfy the standard assumptions

\footnotetext{
${ }^{1}$ In the first model of vertical product differentiation developed by Mussa and Rosen (1978) consumers differ not by income but by taste for quality. However, Tirole (1988) shows that the consumer's taste variable introduced by Mussa and Rosen (1978) gives the reciprocal value of the marginal rate of substitution between income and quality. Intuitively speaking, wealthier consumers value money (income) less and are therefore more willing to pay for an additional unit of quality. See Tirole, 1988, pp. 96-97.

${ }^{2}$ By "coveredness" of the market we mean a characterization whether at equilibrium all consumers willing to buy the market good purchase one of the available qualities so that market (demand) is "covered" or there are consumers who choose the outside option (to buy a free non-market good) instead, so that the market (demand) is "non-covered".
} 
of the models of vertical product differentiation as defined by Gabszewicz and Thisse (1979), Shaked and Sutton (1982, 1983), viz. indivisible and mutually exclusive purchases (i.e. consumers buy only one unit of the good or none), heterogenous consumer incomes, and unanimously agreed ranking of the goods by quality. Examples include the automotive industry, real estate, furniture manufacturing, travel, electronics, and others. In some of these industries, however, goods are also characterized by the property that consumers encounter extra expenses of owning and using them. For instance in the example given by Gabszewicz and Thisse (1979) of the market for pianos, the expenditure incurred by the pianist includes not only the producer's price of the piano itself, but also sales tax, the transportation fee to move the piano from the shop to her (or his) home, the fee for the piano technician to tune it after transport, the warranty against hidden defects that might be revealed after the sale, insurance against damage due to external factors like fire or flood, spare keys and strings, etc.

The expenses that consumers pay on top of the producer's price could be divided into two categories: expenses that vary with the quality of the good (e.g. sales tax, insurance premium, spare keys and strings) and expenses that are constant in the good's quality (e.g. transportation fee, tuning fee).

As long as the producer's price is positively correlated with the quality of the good, each of the first type of expenses affects a consumer's optimal decision the same way as sales tax by increasing the total sum of money a consumer pays for the good proportionally to the producer's price. Accordingly, consumers with income that exceeds the producer's price of given quality but not sufficiently to cover its price after tax will buy a lesser quality which is sold at a lower and therefore affordable price and tax respectively. 
This outcome is identical with the solution for the case of ad valorem tax imposed on producers which is extensively studied in the literature.

Cramer and Thisse (1994) investigate the special case when the minimum income exceeds the producer's price of the second-best quality sufficiently to cover its corresponding proportional tax. As a result, at equilibrium the market remains covered by two firms only. Distinct from the no-tax case, however, the market share of the high-quality producer will shrink in favor of the low-quality producer.

Constantatos and Sartzetakis (1999) analyze the alternative situation when minimum income cannot cover the after-tax price of the low-quality good. The corresponding equilibrium solution implies that the consumer would switch to a worse-quality good which will open space for at least one more firm to enter the market. The cost advantage of the low-quality firm is enhanced by the ad valorem tax and at a high rate takes dominance over the quality advantage of the high-quality firm. Accordingly, the condition for having a finite number of entrants in equilibrium ${ }^{3}$ holds only for low ad valorem tax rates.

In this paper we focus our attention on the second type of expenses, which are constant in the quality of goods and affect the consumer's choice similarly to a lump-sum consumption tax. ${ }^{4}$ To our knowledge the effect of lump-sum taxation on consumption in a vertically differentiated market has not been studied in the existing literature. Brécard (2008) models the effect of unit commodity taxation on producers' sales in an exogenously set non-covered duopoly market. Instead we propose a model with endogenous entry and explore how the condition for covered market duopoly changes in

\footnotetext{
${ }^{3}$ The characteristic of the vertically differentiated markets to have a finite equilibrium number of entrants even at sunk cost that tend to zero is called finiteness property and is rigorously defined by Shaked and Sutton (1983).

${ }^{4} \mathrm{We}$ are grateful to Jakub Steiner for pointing out the similarity between exogenous expense and lump-sum consumption tax in his comments to an earlier version of the present paper.
} 
the amount of the lump-sum tax imposed on consumption of the vertically differentiated market good.

In our model, tax changes the equilibrium price not by increasing firm's cost, that is by shifting the supply curves down. Instead, it negatively affects a buyer's net income, which shifts the residual demand curves down. As a result, we are able to study the equilibrium solution in a setting maximally close to the original model of Shaked and Sutton (1982) so that we do not need to relax even its simplifying assumption for zero unit production cost.

Our results suggest the existence of three distinct equilibrium outcomes dependent on the amount of the lump-sum payment imposed on consumers.

The first equilibrium outcome is similar to the case of proportionate taxation in the model of Cramer and Thisse (1994). For small lump sum tending to zero, the equilibrium outcome is covered duopoly. Only the demand share of the high-quality firm decreases proportionally to the amount of the exogenous expense in favor of the market share of the low-quality producer.

The second equilibrium outcome corresponds to a medium lump sum which does not tend to zero but is still below the level at which consumers who would otherwise buy the low quality cannot afford it. As a result, some (although not all) of the consumers of the low-quality firm switch to the free outside option and the market is a non-covered duopoly at equilibrium.

The third equilibrium outcome occurs at and above the lump-sum threshold where only consumers who prefer the best quality buy the market good. Then, the producer of the low-quality good cannot have a positive market share. The consumers who do not buy the 
best good choose the free outside option. So, the low-quality firm loses incentive to enter the market and there is a non-covered monopoly structure at equilibrium.

Another distinct feature of the model we propose is that the choice of quality is exogenously restricted from above, so that each firm faces an individual upper limit representing the best quality it could produce (e.g. due to patent protection or variability in the quality of the inputs accessible by the different producers). On the one hand, this allows us to derive an explicit solution for the optimal qualities. On the other hand, it ensures distinct quality choices of the firms as well as clear identification of the entrant who offers the best quality at equilibrium.

The paper is organized as follows. Section 2 describes the model of a vertically differentiated market with lump-sum taxation on consumption. Section 3 presents each of the three equilibrium solutions, covered duopoly, non-covered duopoly and non-covered monopoly, with the respective conditions on the amount of the lump-sum payment and income distribution expressed in terms of the quality constraints of the goods. Section 4 summarizes the results and discusses their implications.

\section{The Model}

Here we introduce a model of a market for vertically differentiated goods with lump-sum tax imposed on consumers who use them. To allow for direct comparability the notation of the common terms is held the same as in Shaked and Sutton (1982).

Consider $N$ independent firms who are potential entrants to the market. They face the following three-stage game:

Stage 1: Firms decide to enter the market or not. 
Before making an entry decision each potential entrant is assigned an individual exogenously defined upper bound on its quality. ${ }^{5}$ Each potential entrant is identified by the sequential number $n \in[1, N]$ of its quality bound $\left(\bar{u}_{n}\right)$ in descending order:

$$
\bar{u}_{1}>\bar{u}_{2}>\bar{u}_{3}>\ldots>\bar{u}_{n}>\bar{u}_{n+1}>\ldots>\bar{u}_{N}
$$

where:

$\bar{u}_{n}$ - upper bound on quality choice with rank $\mathrm{n}, n=1,2, \ldots, N$.

Based on its assignment, each firm independently decides whether to enter the market or not. In the real world firms may face quality constraints like in (1) if for example quality-enhancing technologies are patent-protected ${ }^{6}$.

Stage 2: Entrants make a quality choice.

Let $\mathrm{K}$ entrants be in the market after the first stage, $K \leq N$. Each actual entrant is identified by the sequential number $k \in[1, K]$ of its quality bound $\left(\bar{u}_{n_{k}}\right)$ in a subsequence of the initial sequence in (1). The subsequence is formed by arranging in descending order the quality bounds of the actual entrants only. ${ }^{7}$ Accordingly, each entrant $k$ chooses the quality $u_{k}(k=1,2, \ldots, K)$ of its good so that the following inequality must hold: ${ }^{8}$

$$
u_{k} \leq \bar{u}_{n_{k}}, k=1,2, \ldots, K, K<N
$$

\footnotetext{
${ }^{5}$ This assumption ensures only distinct quality choices in equilibium. For a solution without quality constraints which allows also for classical Bertrand homogenous-good equilibrium see Shaked and Sutton, 1982, p.10.

${ }^{6}$ For a stylized model of patent race see Loury (1979).

${ }^{7}$ Alternatively, qualities could be indexed in ascending order as in Shaked and Sutton (1982). Here, we arrange them in descending order, to make indices independent on the number of entrants so that the entrant with highest quality is always indexed by number 1, the entrant with the second-best quality is indexed by 2 and so on till the last entrant who is indexed by $K$.

${ }^{8}$ In our model the rank $k$ of a good in the quality constraint sequence is meant to play the same role of a unique quality identifier as its brand does in the real world. Hereby, we are able to unambiguously determine which potential entrant will enter as a quality leader, and which one as its immediate follower.
} 
where:

$u_{k}$ - quality choice of entrant with upper-bound re-ranked to $k$

$\bar{u}_{n_{k}}$ - k-th element of subsequence from sequence $\left\{\bar{u}_{n}\right\}_{n=1}^{N}$

Stage 3: Firms compete in prices

Each firm makes a take-it-or-leave-it offer in the form of quality-price pair. For simplicity, as in Shaked and Sutton (1982) the production costs are assumed to be zero. Therefore, each firm sets the price that maximizes its revenue as it is given by the product of the price and the corresponding demand for quality it has chosen in the second stage:

$$
\max _{p_{k}, u_{k}} R_{k}=p_{k} D_{k}\left(p_{1}, \ldots, p_{k}, \ldots, p_{K}\right), k=1, \ldots, K
$$

where:

$R_{k}$ - revenue of the entrant providing good with quality rank $\mathrm{k}$ in the market, $k=$ $1,2, \ldots, K$

$p_{k}$ - price of good with quality rank $\mathrm{k}$

$D_{k}\left(p_{1}, \ldots, p_{k}, \ldots, p_{K}\right)$ - demand for good with quality rank $\mathrm{k}$

The demand for a quality-ranked good coincides with the number of consumers who choose to buy it. This is implied by the standard assumption that consumers make indivisible and mutually exclusive purchases (i.e. buy one or none) from among the $K$ qualities available in the market. ${ }^{9}$ Consumers are also assumed to form a continuum so that there is no difference between market share and demand for quality. To explicitly derive the market shares of the qualities in the market, the consumer's side of the market

\footnotetext{
$9 " .$. this is necessarily the case if the choice of a consumer concerns indivisible products which, by their very nature, are either bought in a single unit of a single brand or not bought at all. So are cars, TV's, washing machines, stereo chains, pianos, a.s.o." (Gabszewicz and Thisse, 1979, p. 340)
} 
is defined below.

The market good is modelled as a non-perfect substitute of a composite good representing the rest of the consumption. This is a reasonable assumption given that we introduce a lump-sum tax to take account of the possible presence of perfect complements, which are consumed together with the market good. The expenditures on the market good and the composite good are assumed to have an equal constant share of the consumer's income. Solving the model for different expenditure shares of the market good and the composite good, although technically possible, does not affect the structure and the coveredness of the market at equilibrium. The corresponding consumer's preferences are given by the following utility function of a simplified Cobb-Douglas form:

$$
U(k, x)=u_{k} x
$$

where:

$U(k, x)$ - utility function of a consumer who buys good with quality rank $k$

$x$ - the consumption of all the other goods represented by the quantity of a composite good that is accordingly taken to be a numéraire good with a unit price.

As is standard for the non-representative consumer models of product differentiation, the identifying characteristics of consumers, which in our model is their gross income, is assumed to be uniformly distributed according to a density that equals unity on some support $0<a \leq t \leq b$. Respectively, each consumer maximizes her (or his) utility subject to the following budget constraint:

$$
p_{k}+x \leq t-T
$$


where:

$t$ - gross consumer income,

$$
t \sim U[a, b]
$$

$T$ - amount of the lump-sum tax imposed on the consumption of the market good.

So long as both prices are positive, the consumer problem has an internal solution, so that the budget constraint is binding. This allows the amount of the numéraire good consumed to be expressed through the prices and consumer's budget as follows:

$$
x=t-T-p_{k}
$$

Substituting for $x$ in the objective function yields the following unconstrained consumer's optimization problem:

$$
\max _{k} U(k, t)=u_{k}\left(t-T-p_{k}\right)
$$

This reduced-form utility function is directly assumed to represent the common consumer preferences by Gabszewicz and Thisse (1979) and Shaked and Sutton (1982).

To rule out a situation where a consumer participates in the market although her (or his) budget cannot cover the tax and price of either of the available qualities, a free non-taxable outside offer is also made available to the consumers. It has a quality of $u_{0}$ and zero price $p_{0}=0$ at which the utility function in (8) takes the following reduced form:

$$
U(k=0, t)=u_{0} t
$$

Note that the utility from the outside option is always non-negative even when the 
consumer that chooses it has zero gross income.

The derivation of the quality demand shares follows from the solution of the optimization problem in (8). Note that (8) implies that the utility from good with quality rank $k$ increases linearly in the gross income of the consumer. Therefore, on figure 1 the curve representing the utility from quality $u_{k}$ as a function of consumer's gross income is a straight line. ${ }^{10}$

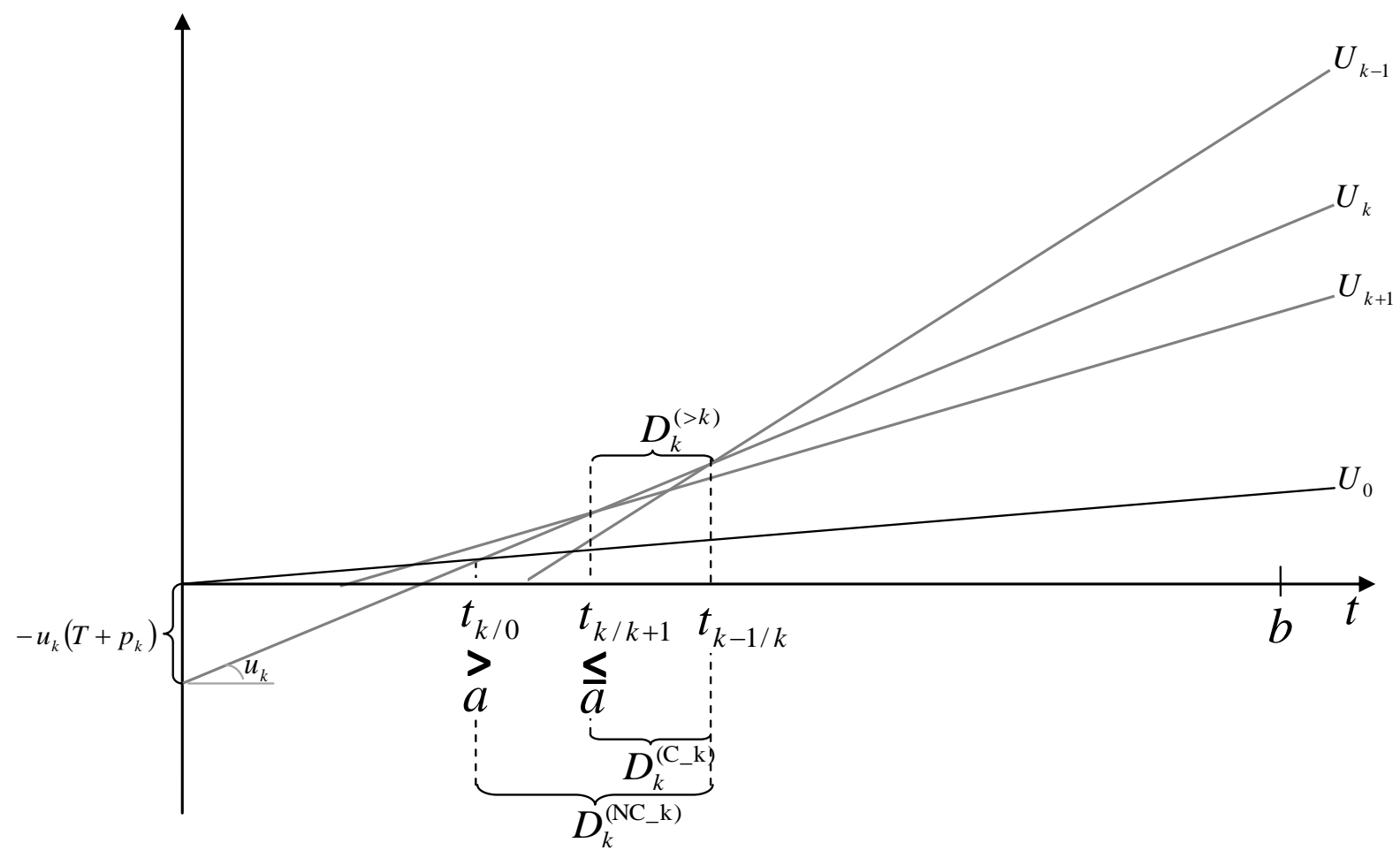

Figure 1: Deriving the quality demand shares as solutions to the utility-maximization problems

The market share of quality $u_{k}$ is given by the intersection of the two subsets $\left[t_{k / k+1}, t_{k-1 / k}\right]$ and $[a, b]$ that gives the subset of the feasible consumer incomes at which its utility (line) is the highest. $D_{k}^{(\mathrm{C}-\mathrm{k})}$ represents the market share of $u_{k}$ when it covers the market $\left(t_{k / k+1} \leq a\right)$. $D_{k}^{(\mathrm{NC}-\mathrm{k})}$ represents the market share of $u_{k}$ when it is the lowest quality but the market is non-covered $\left(t_{k / 0}>a\right) . D_{k}^{(>k)}$ represents the market share of $u_{k}$ when there is a lower quality $u_{k+1}(K>k)$.

\footnotetext{
${ }^{10} \mathrm{~A}$ graph similar to Figure 1 has been employed by Giannakas (2011) to illustrate the derivation of market shares in a model of vertically differentiated market without additional expense and outside option.
} 
On Figure 1 the crossing point between any two utility curves gives the marginal gross income at which a consumer would be indifferent between the qualities they represent. Particularly, at marginal income $t_{k-1 / k}$ consumer is indifferent between quality $u_{k-1}$ and quality $u_{k}$ while at marginal income $t_{k / k+1}$ consumer is indifferent between quality $u_{k}$ and quality $u_{k+1}$.

The assumptions for unit-consumption and uniform distribution of incomes in the interval $[a, b]$ imply that the market share of quality $u_{k}$ is given by the intersection of the two subsets of the set of possible consumer incomes, $\left[t_{k / k+1}, t_{k-1 / k}\right]$ and $[a, b]$. Accordingly, there are three possibilities.

First, if the marginal incomes $t_{k-1 / k}$ and $t_{k / k+1}$ belong to the support interval of the consumer income distribution, $t_{k / k+1} \in[a, b] \cup t_{k-1 / k} \in[a, b]$, both $u_{k}$ and $u_{k+1}$ would have positive market share so that $u_{k}$ is not the lowest quality in the market, $(K>k)$. To distinguish the market share in this case, we denote it by $(>k)$.

Second, if $t_{k-1 / k}$ belongs to the support interval of the consumer income distribution and $t_{k / k+1}$ is excluded from it, $t_{k-1 / k} \in[a, b] \cup t_{k / k+1} \notin[a, b], u_{k}$ will be the lowest quality with positive market share. Given that the lowest-income consumer prefers it to the quality of the outside option $u_{0}$, i.e. $t_{k / 0} \leq a$, it will also cover the market. Therefore, we denote this case by $(C k)$.

Third, when $u_{k}$ is the lowest quality with positive market share but the lowest-income consumer prefers the outside option $u_{0}$ to it, i.e. $t_{k / 0}>a$, the market is not covered. We denote this case by $\left(N C \_k\right)$.

Hence, the market share of quality $u_{k}$ is represented by the following conditional equation: 


$$
D_{k}= \begin{cases}D_{k}^{(C\lrcorner k)}=t_{k-1 / k}-a, & \text { if } t_{k / k+1}<t_{k / 0} \leq a<t_{k-1 / k}<b \\ D_{k}^{(N C-k)}=t_{k-1 / k}-t_{k / 0}, & \text { if } t_{k / k+1} \leq a<t_{k / 0}<t_{k-1 / k}<b \\ D_{k}^{(>k)}=t_{k-1 / k}-t_{k / k+1}, & \text { if } \max \left[t_{k+1 / 0}, a\right]<t_{k / k+1}<t_{k-1 / k}<b \quad(\mathrm{k}=2, \ldots, \mathrm{K}) \\ 0, & \text { if } t_{k / k+1}<t_{k-1 / k} \leq a<b\end{cases}
$$

where:

$D_{k}-$ demand share of good with quality rank $k$

$D_{k}^{\left(C \_k\right)}$ - demand share of good with quality rank $k$ when it covers $(\mathrm{C})$ the market $\left(t_{k / k+1} \leq a\right), k=2, \ldots, K$

$D_{k}^{(N C k)}-$ demand share of good with quality rank $k$ when it has the lowest quality but the market is non-covered (NC) $\left(t_{k / 0}>a\right)$

$D_{k}^{(>k)}$ - demand share of good with quality rank $k$ when its quality is not the lowest in the market $(K>k)$

We ignore the case when $t_{k / k+1}$ belongs to the support interval of the consumer income distribution and $t_{k-1 / k}$ is excluded from it, $t_{k / k+1} \in[a, b] \cup t_{k-1 / k} \notin[a, b]$, because by definition this cannot be an equilibrium outcome. The higher quality rank (as unanimously agreed by all consumers) of $u_{k-1}$ relative to $u_{k}$ implies that the former cannot be efficiently undercut by the latter at equilibrium. On the contrary, even if quality $u_{k-1}$ is priced slightly higher than $u_{k}$, it would still be preferred by the consumer at any income level.

When $k=1$, however, there is no better quality in the market, so its demand share is bounded from above by the maximum income $b$ itself, as shown below: 


$$
D_{1}= \begin{cases}D_{1}^{(C\lrcorner k)}=b-a, & \text { if } t_{1 / 2}<t_{1 / 0} \leq a<b \\ D_{k}^{(N C\lrcorner k)}=b-t_{1 / 0}, & \text { if } t_{1 / 2} \leq a<t_{1 / 0}<b \\ D_{k}^{(>1)}=b-t_{1 / 2}, & \text { if } \max \left[t_{2 / 0}, a\right]<t_{1 / 2}<b \\ 0, & \text { if } a<b<t_{1 / 2}\end{cases}
$$

Finally, the demand functions $D_{k}\left(p_{1}, \ldots, p_{k}, \ldots, p_{K}\right), k=1, . ., K$, in (3) could be derived in explicit form by expressing the demand shares in (10) and (11) in terms of prices. For the purpose, we need to first express the marginal incomes. The general expression for the marginal consumer's income $t_{k / k+1}$ can be derived from equalizing the utility function as defined in (8) for $u_{k}$ and $u_{k+1}$ :

$$
U\left(k, t_{k / k+1}\right)=U\left(k+1, t_{k / k+1}\right)
$$

which after being solved for $t_{k / k+1}$ in explicit terms yields the following result:

$$
t_{k / k+1}=\frac{u_{k+1} p_{k+1}-u_{k} p_{k}}{u_{k+1}-u_{k}}+T
$$

where:

$t_{k / k+1}$ - the marginal gross income that would make a consumer indifferent between buying quality $u_{k}$ or quality $u_{k+1}$ at the market prices at which these qualities are supplied given the lump-sum tax $T$.

The expression for the income at which the utility curves of $u_{k}$ and $u_{0}$ cross each another can be derived in the same way but it differs from (13) because the outside option 
is free and non-taxable:

$$
t_{k / 0}=\frac{u_{k} p_{k}}{u_{k}-u_{0}}+\frac{u_{k}}{u_{k}-u_{0}} T
$$

The corresponding double-kinked demand curve of $u_{k}$ is given by the following expression:

$$
D_{k}= \begin{cases}\frac{u_{k-1} p_{k-1}-u_{k} p_{k}}{u_{k-1}-u_{k}}+T-a, & \text { if } p_{k} \leq \hat{p}_{k} \quad\left(\mathrm{C} \_\mathrm{k}\right) \\ \frac{u_{k-1} p_{k-1}-u_{k} p_{k}}{u_{k-1}-u_{k}}-\frac{u_{k} p_{k}}{u_{k}-u_{0}}-\frac{u_{0}}{u_{k}-u_{0}} T, & \text { if } \hat{p}_{k}<p_{k}<\hat{\hat{p}}_{k} \quad\left(\mathrm{NC} \_\mathrm{k}\right) \quad \mathrm{k}=2, \ldots, \mathrm{K} \\ \frac{u_{k-1} p_{k-1}-u_{k} p_{k}}{u_{k-1}-u_{k}}-\frac{u_{k} p_{k}-u_{k+1} p_{k+1}}{u_{k}-u_{k+1}}, & \text { if } \hat{\hat{p}}_{k}<p_{k}<\bar{p}_{k} \quad(>\mathrm{k}) \\ 0, & \text { if } p_{k} \geq \bar{p}_{k}\end{cases}
$$

where:

$\hat{p}_{k}=\frac{u_{k}-u_{0}}{u_{k}} a-T-$ price level at which there is a kink in the demand for the good with quality rank $k$ because below that price it covers the market.

$\hat{\hat{p}}_{k}=\frac{u_{k+1}\left(u_{k}-u_{0}\right) p_{k+1}+u_{0}\left(u_{k}-u_{k+1}\right) T}{u_{k}\left(u_{k+1}-u_{0}\right)}-$ price level at which there is another kink in the demand for the good with quality rank $k$ because below that price it undercuts the goods with worse qualities in the market.

$$
\bar{p}_{k}=\frac{u_{k-1}\left(u_{k}-u_{k+1}\right) p_{k-1}+u_{k+1}\left(u_{k-1}-u_{k}\right) p_{k+1}}{u_{k}\left(u_{k-1}-u_{k+1}\right)}-\text { price level at and above which for any }
$$
consumer's income the good with quality rank $k$ is less preferred to its neighbors by rank which excludes it from the market.

The if-conditions in (15) can be also imposed on $T$. For example the condition for the market to be covered by the last entrant $K$ is: 


$$
T \leq \frac{u_{K}-u_{0}}{u_{K}} a-p_{K}^{\left(C_{-} K\right)}
$$

where:

$p_{\mathrm{K}}^{\left(C \_K\right)}$ - optimal price of the last entrant with quality rank $K$ if it is expected to cover the market

Similarly, the condition for the market to be non-covered by the last entrant $K$ is:

$$
T>\frac{u_{K}-u_{0}}{u_{K}} a-p_{K}^{(N C K)}
$$

where:

$p_{\mathrm{K}}^{\left(N C_{-} K\right)}-$ optimal price of the last entrant with quality $\operatorname{rank} K$ if it is expected not to cover the market

The demand function for the best quality in terms of prices is also double-kinked:

$$
D_{1}=\left\{\begin{array}{cl}
b-a, & \text { if } p_{1} \leq \hat{p}_{1} \quad\left(\mathrm{C}_{-} 1\right) \\
b-\frac{u_{1} p_{1}}{u_{1}-u_{0}}-\frac{u_{1} T}{u_{1}-u_{0}}, & \text { if } \hat{p}_{1}<p_{1} \leq \hat{\hat{p}}_{1} \quad\left(\mathrm{~N}_{-} 1\right) \\
b-\frac{u_{1} p_{1}-u_{2} p_{2}}{u_{1}-u_{2}}-T, & \text { if } \hat{\hat{p}}_{1}<p_{1}<\bar{p}_{1} \quad(>1) \\
0, & \text { if } p_{1} \geq \bar{p}_{1}
\end{array}\right.
$$

where:

$\hat{p}_{1}=\frac{u_{1}-u_{0}}{u_{1}} a-T-$ price level at which there is a kink in the demand curve of the good with quality rank 1 because below that price it covers the market.

$\hat{\hat{p}}_{1}=\frac{u_{2}\left(u_{1}-u_{0}\right) p_{2}+u_{0}\left(u_{1}-u_{2}\right) T}{u_{1}\left(u_{2}-u_{0}\right)}-$ price level at which there is another kink in the demand curve of the good with quality rank 1 because below that price it undercuts the goods with 
worse qualities in the market.

$\bar{p}_{1}=\frac{u_{2} p_{2}+\left(u_{1}-u_{2}\right)(b-T)}{u_{1}}-$ price level at and above which for any consumer's income good with quality rank 1 is less preferred to its neighbor by rank which excludes it from the market.

Note that both the expressions in (15) and (18) consist of three distinct linear functions that are related differently to price and tax. For example, the $(\mathrm{C}-\mathrm{k})$ segment of the conditional demand function in (15) is less sensitive to price $p_{k}$ (i.e. steeper) than the (NC k) segment. The former is positively related to the amount of the lump sum (i.e. parallelly shifting to the right when $T$ increases) while the latter is negatively related to the amount of the lump sum (i.e. parallelly shifting to the left when $T$ increases). Therefore, at different amounts of the lump sum, the residual demand curves change not only their locations but also their shapes, which implies a difference in the segment to which the optimal solution belongs.

In the next section, we apply the concept of Selten's (1975) subgame perfect equilibrium and solve the model by backwards induction to identify three distinct optimal outcomes characterized by the structure and the coveredness of the market at different lump sums of the tax on consumption.

We first derive the conditions on $a, b$ and $T$ for having a covered duopoly outcome at equilibrium and show that it is not independent of the quality choices of the entrants. Further, we specify the conditions on the individual quality upper bounds for having alternative equilibrium solutions at larger amounts of the lump sum, respectively non-covered duopoly and non-covered monopoly. 


\section{Subgame-Perfect Equilibrium Solutions}

\subsection{Covered Duopoly Equilibrium with Small Lump-sum Tax Tending to Zero}

Given $\mathrm{K}$ entrants in the market, we can express explicitly their revenue-maximization problems by substituting for the demand function from (15) and (18) in (3):

$$
\begin{gathered}
\max _{p_{1}, u_{1}} R_{1}=p_{1}\left(\bar{\theta}-\frac{u_{1} p_{1}-u_{2} p_{2}}{u_{1}-u_{2}}\right) \\
\max _{p_{k}, u_{k}} R_{k}=p_{k}\left(\frac{u_{k-1} p_{k-1}-u_{k} p_{k}}{u_{k-1}-u_{k}}-\frac{u_{k} p_{k}-u_{k+1} p_{k+1}}{u_{k}-u_{k+1}}\right), k=2, \ldots, K-1 \\
\max _{p_{K}, u_{K}} R_{K}= \begin{cases}p_{K}\left(\frac{u_{K} p_{K}-u_{K+1} p_{K+1}}{u_{K}-u_{K+1}}-a\right), & \text { if } p_{\mathrm{K}} \leq \frac{u_{K}-u_{0}}{u_{K}} a-T \\
p_{K}\left(\frac{u_{K} p_{K}-u_{K+1} p_{K+1}}{u_{K}-u_{K+1}}-\frac{u_{K} p_{K}}{u_{K}-u_{0}}\right), & \text { if } p_{\mathrm{K}}>\frac{u_{K}-u_{0}}{u_{K}} a-T\end{cases}
\end{gathered}
$$

The optimal solution for prices in the last subgame implies the following sequence of inequality relationships between the marginal incomes $t_{k / k+1}$ and the support interval bounds $a$ and $b$ of the consumer income distribution: ${ }^{11}$

$$
\begin{aligned}
& b \geq 2 t_{1 / 2}-T \geq 4 t_{2 / 3}-3 T \geq \ldots \geq 2^{k} t_{k / k+1}-\left(2^{k}-1\right) T \geq \\
& \geq \begin{cases}2^{K-1} a-\left(2^{K-1}-1\right) T, & \text { if } p_{\mathrm{K}}^{\left(C \_K\right)} \leq \frac{u_{K}-u_{0}}{u_{K}} a-T \\
2^{K} t_{K / 0}-\left(\frac{\left(2^{K}-1\right) u_{K}-\left(2^{K-1}-1\right) u_{0}}{u_{K}-u_{0}}\right) T, & \text { if } p_{\mathrm{K}}^{\left(N C \_K\right)}>\frac{u_{K}-u_{0}}{u_{K}} a-T\end{cases}
\end{aligned}
$$

Hence, if the maximum income $b$ satisfies the constraint below:

\footnotetext{
${ }^{11}$ The result in (22) is derived from the system of revenue-maximizing first-order conditions with respect to prices as in Shaked and Sutton, 1982, p.5.
} 


$$
b \leq 4 a-3 T
$$

the following inequality would characterize the equilibrium with more than two entrants:

$$
a>t_{k-1 / k}>t_{k / 0}, k=3, \ldots, K \text { for } K>2
$$

That is, when (23) holds for all the firms that decide to enter the market at the first stage, at most two would have positive market share and therefore would remain in the market at equilibrium. Note that this result is not affected by the coveredness of the market. So, (23) would ensure efficient foreclosure of a potential third entrant $\left(a>t_{2 / 3}\right)$ even in the case of non-covered equilibrium market outcome, which is studied in the next subsection.

In this subsection, we are interested in the conditions for having a covered duopoly at equilibrium. Therefore, we assume that condition (23) holds and the market is covered by two entrants with ranks 1 and 2, respectively. The corresponding subgame equilibrium is given by the following expressions for the optimal prices in terms of the qualities of the goods the two firms offer:

$$
\begin{aligned}
& p_{1}^{\left(C_{-} 2\right)}=\frac{(2 b-a-T)\left(u_{1}^{\left(C_{-} 2\right)}-u_{2}^{\left(C_{-} 2\right)}\right)}{3 u_{1}^{\left(C_{-} 2\right)}} \\
& p_{2}^{\left(C_{-} 2\right)}=\frac{(b-2 a+T)\left(u_{1}^{\left(C_{-} 2\right)}-u_{2}^{\left(C_{-} 2\right)}\right)}{3 u_{2}^{\left(C_{-} 2\right)}}
\end{aligned}
$$

where:

$p_{1}^{\left(C_{-} 2\right)}-$ price choice of firm 1 in the case of a covered duopoly equilibrium 
$p_{2}^{\left(C_{-} 2\right)}-$ price choice of firm 2 in the case of a covered duopoly equilibrium $u_{1}^{(C-2)}$ - quality choice of firm 1 in the case of a covered duopoly equilibrium $u_{2}^{\left(C_{2}-2\right)}-$ quality choice of firm 2 in the case of a covered duopoly equilibrium The optimal expressions for demands are:

$$
\begin{aligned}
& D_{1}^{\left(C \_2\right)}=\frac{1}{3}(2 b-a-T) \\
& D_{2}^{\left(C \_2\right)}=\frac{1}{3}(b-2 a+T)
\end{aligned}
$$

where:

$D_{1}^{\left(C \_2\right)}-$ market share of firm 1 in the case of a covered duopoly equilibrium $D_{2}^{(C-2)}-$ market share of firm 2 in the case of a covered duopoly equilibrium

Both expressions in (26) are positive if the maximum income $b$ satisfies the constraint below:

$$
b>2 a-T
$$

Combining conditions (23) and (27) give us the following inequality:

$$
2 a-T<b \leq 4 a-3 T
$$

that must be satisfied for having two entrants with positive market shares at equilibrium provided that the market is covered. Note that in case of zero additional expense to the consumer, $T=0$, the inequality in(28) coincides with the Shaked and Sutton's (1982) condition for a covered duopoly equilibrium. Distinct from this, however, there are some sufficiently large positive values of $T$ for which (28) would not hold. For its right-hand 
side to be larger than its left-hand side, the tax should not exceed the minimum consumer income $a$.

$$
T<a
$$

Condition (23) is not sufficient to have a covered market equilibrium at $T>0$. For the purpose, we introduce an additional condition on $T$ which is not independent of the quality choices of the firms at the second stage. Before deriving it, we need first to present the solution for the quality-choice subgame equilibrium at the second stage. We express the revenues of the two entrants in terms of their qualities by taking the pairwise products of the respective expressions in (25) and (26):

$$
\begin{aligned}
& R_{1}^{\left(C \_2\right)}=\frac{(2 b-a-T)^{2}\left(u_{1}^{\left(C \_-2\right)}-u_{2}^{\left(C \_-2\right)}\right)}{9 u_{1}^{\left(C \_-2\right)}} \\
& R_{2}^{\left(C \_2\right)}=\frac{(2 b-a-T)^{2}\left(u_{1}^{\left(C \_-2\right)}-u_{2}^{\left(C \_-2\right)}\right)}{9 u_{1}^{\left(C \_-2\right)}}
\end{aligned}
$$

where:

$R_{1}^{\left(C \_2\right)}-$ profit/revenue of firm 1 in the case of a covered duopoly equilibrium $R_{2}^{\left(C_{2} 2\right)}-$ profit/revenue of firm 2 in the case of a covered duopoly equilibrium

Both expressions in (30) are increasing in the higher quality $u_{1}$ and decreasing in the lower quality $u_{2}$ which implies the following set of optimal quality choices in the second stage: 


$$
\begin{aligned}
& u_{1}^{\left(C_{-}-2\right)}=\bar{u}_{1} \\
& u_{2}^{(C-2)}=\underline{u}_{2}
\end{aligned}
$$

where:

$\underline{u}_{2}$ - the lowest quality that the entrant with quality constraint of rank 2 could choose So that its good is still better than the outside option, $\underline{u}_{2}=u_{0}+\varepsilon, \varepsilon \rightarrow 0, \varepsilon>0$.

We derive the condition for a covered market by substituting for the optimal price $p_{2}^{\left(C \_2\right)}$ from (25) in (16) for $\mathrm{K}=2$ :

$$
T \leq \frac{a\left(2 \bar{u}_{1}+\underline{u}_{2}-3 u_{0}\right)-b\left(\bar{u}_{1}-\underline{u}_{2}\right)}{\bar{u}_{1}+2 \underline{u}_{2}}
$$

Apparently, the condition on $T$ in (32) is stricter than the one in (29).

We can re-write (32) as follows:

$$
b<\frac{\left(2 \bar{u}_{1}+\underline{u}_{2}-3 u_{0}\right) a-\left(\bar{u}_{1}+2 \underline{u}_{2}\right) T}{\bar{u}_{1}-\underline{u}_{2}}
$$

In order (33) to be consistent with the left-hand side inequality in (28), however, $T$ must satisfy also the following condition:

$$
T<\frac{\underline{u}_{2}-u_{0}}{\underline{u}_{2}} a=\frac{\varepsilon}{u_{0}+\varepsilon} a
$$

which implies that the market can be a covered duopoly at equilibrium only if $T$ tends to zero. 
As long as the upper quality constraint on the best-ranked good is sufficiently large relative to the quality of the outside option:

$$
\bar{u}_{1}>\frac{5}{2} \underline{u}_{2}=\frac{5}{2}\left(u_{0}+\varepsilon\right)
$$

the right-hand side inequality in (28) will be stricter than the condition in (33). Accordingly, the joint validity of conditions (28), (34) and (35) would ensure the existence of a covered duopoly equilibrium which is established in proposition 1 below.

Proposition 1. Let the consumer income distribution, the amount of the exogenous expense and the best-ranked quality constraint from above satisfy conditions (28), (34) and (35), respectively. Then, a unique subgame perfect equilibrium exists at which exactly the entrants with quality ranks 1 and 2 enter the market, make the quality choice in (31) and set the corresponding prices in (25). The firms' market shares and profits are given by the respective expressions in (26) and (30). The market is covered.

The intuition behind proposition 1 can be illustrated by plotting the residual demand curves of firm 1 and 2 according to the expressions for their demand functions in (15) and (18) as shown on figure 2 below. Since marginal cost is assumed to be zero for both entrants, the equilibrium solutions are given by the points of unit elasticity in their residual demand curves. That is, if we take the segment to which the unit elasticity point belongs as a linear demand curve itself, the unit elasticity point would be equally distant from its intersections with the hoirizontal and vertical axes. When the additional expense $T$ tends to zero as required in (34), the quality constraint of firm 1 is sufficiently large to satisfy condition (35) and the support interval of the distribution of consumer incomes complies with the inequalities in (28), the unit elasticity points belong to the highest segment of the residual demand curve of firm 1 and to the middle segment of the residual demand curve of firm 2, respectively. 
Generally, the amount of expense $T$ is negatively related to the net income of the buyers in the market. Therefore, its imposition leads to a shift in the residual demand curves. However, the assumption for indivisibility and mutual exclusivity of goods implies that we would not have the classical parallel shift to the left of the overall demand curve. As the expressions in (15) and (18) show, the magnitude and the direction of the demand curve shift varies across its segments. As a result, at different values of $T$ the unit elsticity point would move from one segment to another thus implying distinct equilibrium outcomes.
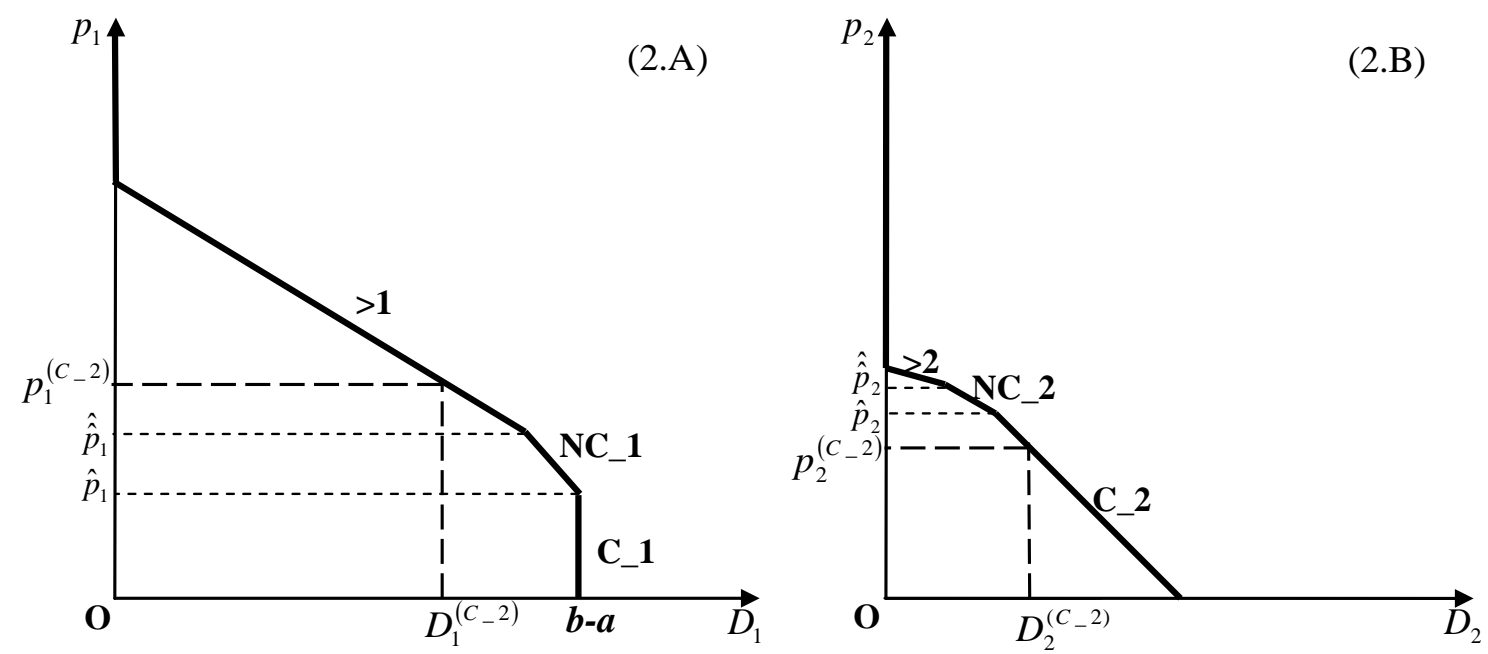

Figure 2: Solution for equilibrium with covered duopoly outcome

Panel (2.A) represents the residual demand curve of a good with quality rank 1 as given in (18) at the small tax established in (34). The optimal solution is given by the unit-elastic point with coordinates $\left(D_{1}^{\left(C_{-} 2\right)}, p_{1}^{\left(C_{-} 2\right)}\right)$ which belongs to the segment $(>1)$ above the price $\hat{\hat{p}}_{1}^{\left(C_{-} 2\right)}$ at which at least one more entrant with a worse good is accommodated in the market. Panel (2.B) illustrates the demand for the good with quality rank 2 as given in (15) for $k=2$ at the small tax established in (34). The optimal solution is given by the unit-elastic point with coordinates $\left(D_{2}^{\left(C_{-} 2\right)}, p_{2}^{\left(C_{-} 2\right)}\right)$ which belongs to the bottom segment $\left(C_{-} 2\right)$ below the price $\hat{p}_{2}$ at which the market is exactly covered by the second-best quality. 


\subsection{Non-Covered Duopoly Equilibrium with Middle Lump-sum Tax}

In this subsection, we establish the conditions for a non-covered duopoly outcome at equilibrium.

Let the condition in (23) hold, so that we have at most two entrants but the market is assumed to be non-covered. The corresponding subgame equilibrium at the pricing stage is given by the set of optimal prices for the two entrants:

$$
\begin{aligned}
& p_{1}^{\left(N C \_2\right)}=\frac{\left.\left(2\left(u_{1}^{\left(N C \_2\right)}-u_{0}\right) b-\left(2 u_{1}^{\left(N C \_2\right)}-u_{0}\right) T\right)\right)\left(u_{1}^{\left(N C \_2\right)}-u_{2}^{\left(N C \_2\right)}\right)}{\left(4 u_{1}^{\left(N C \_2\right)}-u_{2}^{\left(N C \_2\right)}-3 u_{0}\right) u_{1}^{\left(N C \_2\right)}} \\
& p_{2}^{\left(N C \_2\right)}=\frac{\left(\left(u_{2}^{\left(N C \_2\right)}-u_{0}\right) b-\left(u_{2}^{\left(N C \_2\right)}+u_{0}\right) T\right)\left(u_{1}^{\left(N C \_2\right)}-u_{2}^{\left(N C \_2\right)}\right)}{\left(4 u_{1}^{\left(N C \_2\right)}-u_{2}^{\left(N C \_2\right)}-3 u_{0}\right) u_{2}^{\left(N C \_2\right)}}
\end{aligned}
$$

where:

$p_{1}^{\left(N C \_2\right)}$ - price choice of firm 1 in the case of a non-covered duopoly equilibrium $p_{2}^{(N C-2)}$ - price choice of firm 2 in the case of a non-covered duopoly equilibrium $u_{1}^{\left(N C \_2\right)}-$ quality choice of firm 1 in the case of a non-covered duopoly equilibrium $u_{2}^{\left(N C \_2\right)}$ - quality choice of firm 2 in the case of a non-covered duopoly equilibrium The optimal expressions for demands are:

$$
\begin{aligned}
& D_{1}^{\left(N C \_2\right)}=\frac{2\left(u_{1}^{\left(N C \_2\right)}-u_{0}\right) b-\left(2 u_{1}^{\left(N C \_2\right)}-u_{0}\right) T}{4 u_{1}^{\left(N C \_2\right)}-u_{2}^{\left(N C \_2\right)}-3 u_{0}} \\
& D_{2}^{\left(N C_{-} 2\right)}=\frac{\left(\left(u_{2}^{\left(N C \_2\right)}-u_{0}\right) b-\left(u_{2}^{\left(N C_{-} 2\right)}+u_{0}\right) T\right)\left(u_{1}^{\left(N C_{-} 2\right)}-u_{0}\right)}{\left(4 u_{1}^{\left(N C_{-} 2\right)}-3 u_{0}-u_{2}^{\left(N C \_2\right)}\right)\left(u_{2}^{\left(N C \_-2\right)}-u_{0}\right)}
\end{aligned}
$$

where: 
$D_{1}^{\left(N C_{-} 2\right)}-$ market share of firm 1 in the case of a non-covered duopoly equilibrium $D_{2}^{(N C-2)}-$ market share of firm 2 in the case of a non-covered duopoly equilibrium

For both market shares in (37) to be positive, the following inequality must hold:

$$
b>\frac{\left(u_{2}^{\left(N C \_2\right)}+u_{0}\right)}{u_{2}^{\left(N C \_2\right)}-u_{0}} T
$$

which is consistent with (23) as long as the expense $T$ satisfies the following constraint from above:

$$
T<\frac{2\left(u_{2}^{\left(N C \_2\right)}-u_{0}\right)}{2 u_{2}^{\left(N C \_2\right)}-u_{0}} a
$$

After substituting for the optimal prices from (36) in the expressions for the firm's revenues, the optimal expressions of the latter are as follows:

$$
\begin{aligned}
& R_{1}^{\left(N C \_2\right)}=\frac{\left(2\left(u_{1}^{\left(N C \_2\right)}-u_{0}\right) b-\left(2 u_{1}^{\left(N C \_2\right)}-u_{0}\right) T\right)^{2}\left(u_{1}^{\left(N C \_-2\right)}-u_{2}^{\left(N C \_2\right)}\right)}{\left(4 u_{1}^{\left(N C \_2\right)}-u_{2}^{\left(N C \_2\right)}-3 u_{0}\right)^{2} u_{1}^{\left(N C \_2\right)}} \\
& R_{2}^{\left(N C \_2\right)}=\frac{\left(\left(u_{2}^{\left(N C \_2\right)}-u_{0}\right) b-\left(u_{2}^{\left(N C \_2\right)}+u_{0}\right) T\right)^{2}\left(u_{1}^{\left(N C \_2\right)}-u_{0}\right)\left(u_{1}^{\left(N C \_2\right)}-u_{2}^{\left(N C \_2\right)}\right)}{\left(4 u_{1}^{\left(N C \_2\right)}-u_{2}^{\left(N C \_2\right)}-3 u_{0}\right)^{2}\left(u_{2}^{\left(N C \_2\right)}-u_{0}\right) u_{2}^{\left(N C \_2\right)}}
\end{aligned}
$$

where:

$R_{1}^{\left(N C_{-} 2\right)}-$ profit/revenue of firm 1 in the case of a non-covered duopoly equilibrium $R_{2}^{\left(N C_{-} 2\right)}-$ profit/revenue of firm 2 in the case of a non-covered duopoly equilibrium

The revenue of firm 1 is strictly increasing in the value chosen for the quality of its good so long as the following condition on the maximum consumer income $b$ holds: 


$$
b>\frac{2 u_{1}^{\left(N C \_2\right)}-u_{0}}{2\left(u_{1}^{\left(N C \_2\right)}-u_{0}\right)} T
$$

It can be shown that condition (38) is stricter than (41) for any $u_{2}^{N C_{-} 2}<u_{1}^{N C_{-} 2}$, which is always true when (41) holds.

The revenue of firm 2 is strictly decreasing in the value chosen for the quality of its good so long as the following condition on the maximum consumer income $b$ holds:

$$
b<\frac{u_{2}^{\left(N C \_2\right)}+u_{0}}{u_{2}^{\left(N C \_2\right)}-u_{0}} T
$$

The trivial inconsistency between (42) and (38) represents the tradeoff that firm 2 faces between relaxing the price competition through maximum differentiation from the best-ranked good and saving its positive market share in a non-covered market with narrow dispersion of consumers' incomes according to the restriction in (23). When the condition in (38) holds, the revenue of firm 2 is strictly increasing in the value chosen for the quality of its good for any top-ranked quality constraint since by definition $\bar{u}_{1}$ must exceeds the quality of the outside option $u_{0}$ :

$$
\begin{aligned}
& \bar{u}_{1}>\frac{3 u_{0}^{2}+3 u_{0} \underline{u}_{2}+2 \underline{u}_{2}^{2}+\left(\underline{u}_{2}-u_{0}\right) \sqrt{9 u_{0}^{2}+36 u_{0} \underline{u}_{2}+4 \underline{u}_{2}^{2}}}{8 u_{0}}= \\
= & u_{0}+\varepsilon\left(\frac{7 u_{0}+\sqrt{49 u_{0}^{2}+44 u_{0} \varepsilon+4 \varepsilon^{2}}+2 \varepsilon}{8 u_{0}}\right) \rightarrow u_{0} \text { as } \varepsilon \rightarrow 0
\end{aligned}
$$

Maximal differentiation is the profit-maximizing choice in a covered market because firm 2 competes only with firm 1 and faces no competitive pressure from the free outside option. At a larger lump sum which satisfies condition (17), however, consumers are 
more price sensitive so that all prefer the free outside option if the good of firm 2 is not significantly better than it. Therefore, firm 2 has an incentive to offer the best quality as determined by its individual quality constraint. As a result, we have minimal differentiation outcome at the second-stage subgame equilibrium, given by the following set of quality choices: ${ }^{12}$

$$
\begin{aligned}
& u_{1}^{\left(N C_{-} 2\right)}=\bar{u}_{1} \\
& u_{2}^{\left(N C_{-} 2\right)}=\bar{u}_{2}
\end{aligned}
$$

Substituting for the optimal quality choices in (36) allows us to explicitly express the condition for having a non-covered market in (17):

$$
T>\frac{\left(\left(4 \bar{u}_{1}-\bar{u}_{2}-3 u_{0}\right) a-\left(\bar{u}_{1}-\bar{u}_{2}\right) b\right)\left(\bar{u}_{2}-u_{0}\right)}{3 \bar{u}_{1} \bar{u}_{2}-\left(\bar{u}_{1}+2 \bar{u}_{2}\right) u_{0}}
$$

This can be re-written as follows:

$$
b>\frac{4 \bar{u}_{1}-\bar{u}_{2}-3 u_{0}}{\bar{u}_{1}-\bar{u}_{2}} a-\frac{\left(\bar{u}_{2}-u_{0}\right) \bar{u}_{1}+2\left(\bar{u}_{1}-u_{0}\right) \bar{u}_{2}}{\left(\bar{u}_{2}-u_{0}\right)\left(\bar{u}_{1}-\bar{u}_{2}\right)} T
$$

Note that (46) is never consistent with (23) if $T=0$. Therefore, in Shaked and Sutton (1982) the inequalities in (28) are necessary and sufficient conditions for a covered duopoly outcome at equilibrium. Accordingly, figure 3 below illustrates how the imposition of a lump-sum payment that is large enough to satisfy condition (45) makes the existence of a non-covered market equilibrium possible. For the purpose, we use

\footnotetext{
${ }^{12}$ The minimal differentiation outcome is possible due to the heterogeneity in the quality constraints of firms 1 and 2. Otherwise, if both firms faced the same restriction on their quality choices, we would have the classical Bertrand outcome in a market with homogenous goods.
} 
the original graphical representation from Shaked and Sutton (1982), where firms' best price responses are expressed implicitly through their impact on the relation between the marginal taste parameters $t_{1 / 2}$ and $t_{2 / 0}$ :

$$
\begin{gathered}
t_{1 / 2}^{H}=\frac{1}{2}\left[b-t_{2 / 0}(\bar{V}-1)+\bar{C}_{1} T\right] \\
t_{1 / 2}^{L}=\left\{\begin{array}{l}
a+t_{2 / 0}(\underline{V}-1)-\left(\underline{C}_{1}-1\right) T, \text { if } t_{2 / 0} \leq a \\
t_{2 / 0}(\bar{V}+1)-\left(\bar{C}_{1}-1\right) T, \text { if } t_{2 / 0}>a
\end{array}\right.
\end{gathered}
$$

where:

$t_{1 / 2}^{H}-$ implicit best-response function of the high-quality producer, i.e. firm 1

$t_{1 / 2}^{L}-$ implicit best-response function of the low-quality producer, i.e. firm 2

For expositional simplicity and easier comparability to Shaked and Sutton's (1982) results we borrow the following supplementary notations, which here are especially adjusted to reflect the minimum differentiation quality choice of firm 2 at the non-covered market equilibrium:

$$
\begin{aligned}
& \underline{C}_{1}=\frac{\bar{u}_{1}}{\bar{u}_{1}-\underline{u}_{2}} ; \bar{C}_{1}=\frac{\bar{u}_{1}}{\bar{u}_{1}-\bar{u}_{2}}>\underline{C}_{1} \\
& \underline{C}_{2}=\frac{\bar{u}_{2}}{\underline{u}_{2}-u_{0}} ; \bar{C}_{2}=\frac{\bar{u}_{2}}{\bar{u}_{2}-u_{0}}<\underline{C}_{2} \\
& \underline{V}=\frac{\underline{C}_{1}-1}{\underline{C}_{2}}=\frac{\bar{u}_{1}-u_{0}}{\bar{u}_{1}-\underline{u}_{2}} ; \bar{V}=\frac{\bar{C}_{1}-1}{\bar{C}_{2}}=\frac{\bar{u}_{1}-u_{0}}{\bar{u}_{1}-\bar{u}_{2}}>\underline{V}
\end{aligned}
$$



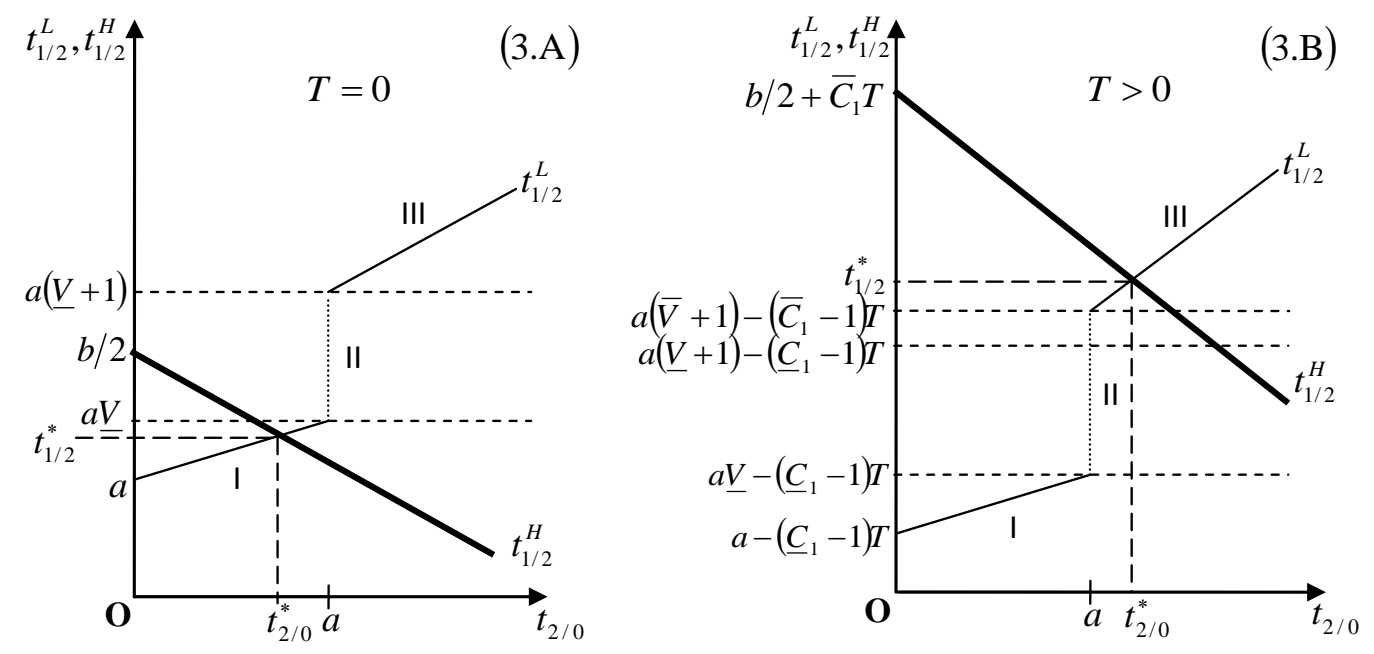

Figure 3: Comparison of the implicit solutions for a covered market equilibrium at $T=0$

and for a non-covered duopoly equilibrium at $T>0$ which satisfies condition (45)

The equilibrium marginal incomes, $t_{2 / 0}^{*}$ and $t_{1 / 2}^{*}$, which demarcate the market shares of firm 1 and firm 2 are given by the coordinates of the point of intersection of their implicit best-response curves, $t_{1 / 2}^{H}$ and $t_{1 / 2}^{L}$, respectively. For the market not to be covered at equilibrium, the solution must belong to the upper right segment of $t_{1 / 2}^{L}$ denoted by III. Panel (3.A) represents the solution without tax suggested by Shaked and Sutton (1982). When the condition in (23) holds given that $T=0$, the vertical intercept of the downward-sloping linear curve $t_{1 / 2}^{H}$ cannot be larger than twice the value of $a$. At the same time, $\underline{V}$ is trivially larger than 1 so that the lowest point of segment III exceeds more than twice $a$. Therefore, the two best-response curves cannot intersect at a point that belongs to segment III i.e. there cannot be a non-covered market at equilibrium when $T=0$. Panel (3.B) represents the solution for positive tax that satisfies condition (45). On the one hand, the vertical intercept increases in $T$. On the other hand, the lowest point of segment 3 shifts down as $T$ increases, which makes it possible the two best-response curves to intersect at a point that belongs to segment III; i.e. there is a non-covered market equilibrium. ${ }^{13}$

Condition (38) is stricter than the constraint in (46), provided that the following condition on $T$ holds:

\footnotetext{
${ }^{13}$ Note also that as the lump sum of the tax $T$ increases, the best-response curve of firm 2 shifts down moving the equilibrium solution below the 45 -degree bisector where $t_{2 / 0}^{*}$ would exceed $t_{1 / 2}^{*}$ so that condition (38) would be violated and firm 2 could not have a positive market share. This gives an incentive to firm 2 to minimize the quality differentiation of its good which shifts up segment III of firm 2's best-response curve and makes it steeper together with the best-response curve of firm 1 .
} 


$$
T>\frac{\bar{u}_{2}-u_{0}}{\bar{u}_{2}} a
$$

Accordingly, conditions (23), (38), (39) and (51) could be combined as follows:

$$
\frac{\bar{u}_{2}+u_{0}}{\bar{u}_{2}-u_{0}} T<b<4 a-3 T \text { for } \frac{\bar{u}_{2}-u_{0}}{\bar{u}_{2}} a<T<\frac{2\left(\bar{u}_{2}-u_{0}\right)}{2 \bar{u}_{2}-u_{0}} a
$$

The inequalities in (52) are sufficient for having a non-covered duopoly outcome at equilibrium. The result is established in proposition 2 below.

Proposition 2. Let the consumer income distribution and the amount of the exogenous expense satisfy condition (52). Then, a unique subgame perfect equilibrium exists at which exactly the entrants with quality ranks 1 and 2 enter the market, make the quality choice in (44) and set the corresponding prices in (36). The firms' market shares and profits are given by the respective expressions in (37) and (40). The market is non-covered.

The intuition behind proposition 2 is illustrated in figure 4 below. Note that the price at the kink $\hat{p}_{2}$ is positive only so long as $T$ is too small to satisfy the condition in (51). Otherwise, for larger $T$ 's the middle segment shifts parallelly to the left while the bottom segment shifts parallely to the right so that the kink between the two segments is moved out of the positive quadrant. That is, there is no positive price of $u_{2}$ at which the lowest-income consumer would prefer it to the free outside option when the inequality in (51) holds. However, the upper-bound constraint in (39) ensures that the optimal price of firm 1 still belongs to the top segment of its residual demand curve. Therefore, the corresponding equilibrium solution implies a non-covered duopoly outcome. 

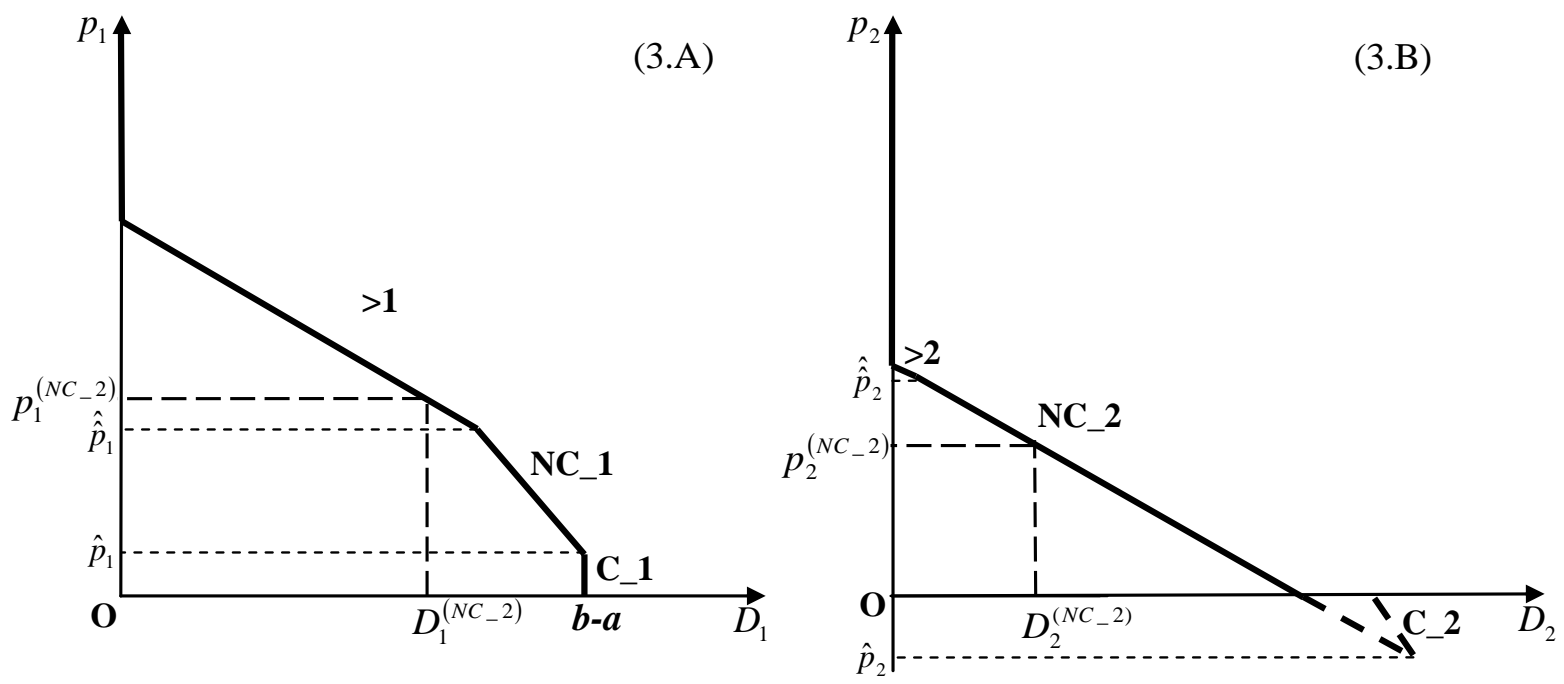

Figure 4: Solution for equilibrium with non-covered duopoly outcome

Panel (4.A) represents the residual demand curve of good with quality rank 1 as given in (18) at a middle lump-sum payment that satisfies (52). The optimal solution occurs at the unit-elastic point with coordinates $\left(D_{1}^{\left(N C_{-} 2\right)}, p_{1}^{\left(N C_{-} 2\right)}\right)$ which belongs to the segment $(>1)$ above the price $\hat{\hat{p}}_{1}$ even though the larger tax in (52) compared to (34) reduces its length in favor of the middle segment. Panel (4.B) illustrates the demand for the good with quality rank 2 as given in (15) for $k=2$ at the middle lump-sum payment that satisfies (52). The optimal solution occurs at the unit-elastic point with coordinates $\left(D_{2}^{\left(N C \_2\right)}, p_{2}^{\left(N C \_2\right)}\right)$ which belongs to the middle segment $\left(N C \_2\right)$ above the price $\hat{p}_{2}$ at which the market is exactly covered by the second-best quality. Therefore, the market is not covered at equilibrium.

\subsection{Non-Covered Monopoly Equilibrium with Large Lump-sum Tax}

The last subsection represents the equilibrium solution at an amount of the lump sum $T$ exceeding the upper-bound constraint in (39) provided that the condition in (23) for having at most two entrants with positive market shares holds.

When condition (39) is not satisfied, condition (38) cannot hold either. Therefore, there can be neither a covered duopoly nor a non-covered duopoly solution if the lump sum of $T$ is defined by the following inequality: 


$$
T \geq \frac{2\left(\bar{u}_{2}-u_{0}\right)}{2 \bar{u}_{2}-u_{0}} a
$$

Since firm 2 cannot make positive sales, it has no incentive to enter the market. So, only firm 1 enters at the first stage and acts as a monopolist. The corresponding subgame-perfect equilibrium is defined by the following price-quality pair:

$$
\begin{aligned}
& p_{1}^{\left(N C_{-} 1\right)}=\frac{\left(u_{1}^{\left(N C_{-} 1\right.}-u_{0}\right) b-u_{1}^{\left(N C_{-} 1\right)} T}{2 u_{1}^{\left(N C_{-} 1\right)}} \\
& u_{1}^{\left(N C_{-} 1\right)}=\bar{u}_{1}
\end{aligned}
$$

where:

$p_{1}^{\left(N C_{-} 1\right)}-$ the optimal price of firm 1 given non-covered monopoly outcome $u_{1}^{\left(N C_{-} 1\right)}$ - the optimal quality choice of firm 1 given non-covered monopoly outcome The expressions for the market share and the revenue of firm 1 are:

$$
\begin{aligned}
& D_{1}^{\left(N C_{-} 1\right)}=\frac{b}{2} \\
& R_{1}^{\left(N C_{-} 1\right)}=\frac{b\left(\left(u_{1}^{N C_{-} 1}-u_{0}\right) b-u_{1}^{\left(N C_{-} 1\right)} T\right)}{4 u_{1}^{\left(N C_{-} 1\right)}}
\end{aligned}
$$

where:

$D_{1}^{\left(N C_{-} 1\right)}$ - the optimal market share of firm 1 given non-covered monopoly outcome $R_{1}^{\left(N C_{-} 1\right)}$ - the optimal revenue of firm 1 given non-covered monopoly outcome A non-covered equilibrium would exist so long as $b$ satisfies the following condition: 


$$
b>2 a
$$

which is consistent with (23) as long as $T$ satisfies the inequality:

$$
T<\frac{2}{3} a
$$

The subgame equilibrium is established in proposition 3 below.

Proposition 3. Let the consumer income distribution and the amount of the exogenous expense satisfy conditions (23), (53), (56) and (57), respectively. Then, a unique subgame perfect equilibrium exists at which only the entrant with quality rank 1 enters the market, makes the quality choice and sets the price in (54). Firm 1's market share and profit are given by the respective expressions in (55). The market is non-covered.

The intuition behind proposition 3 is illustrated in figure 5 below. The middle segment of the resdiual demand curve of firm 1 experiences a parallel shift further to the left when (53) holds. Therefore, the optimal price of firm 1 belongs to the middle segment where consumers buy either the best quality or the free outside option.
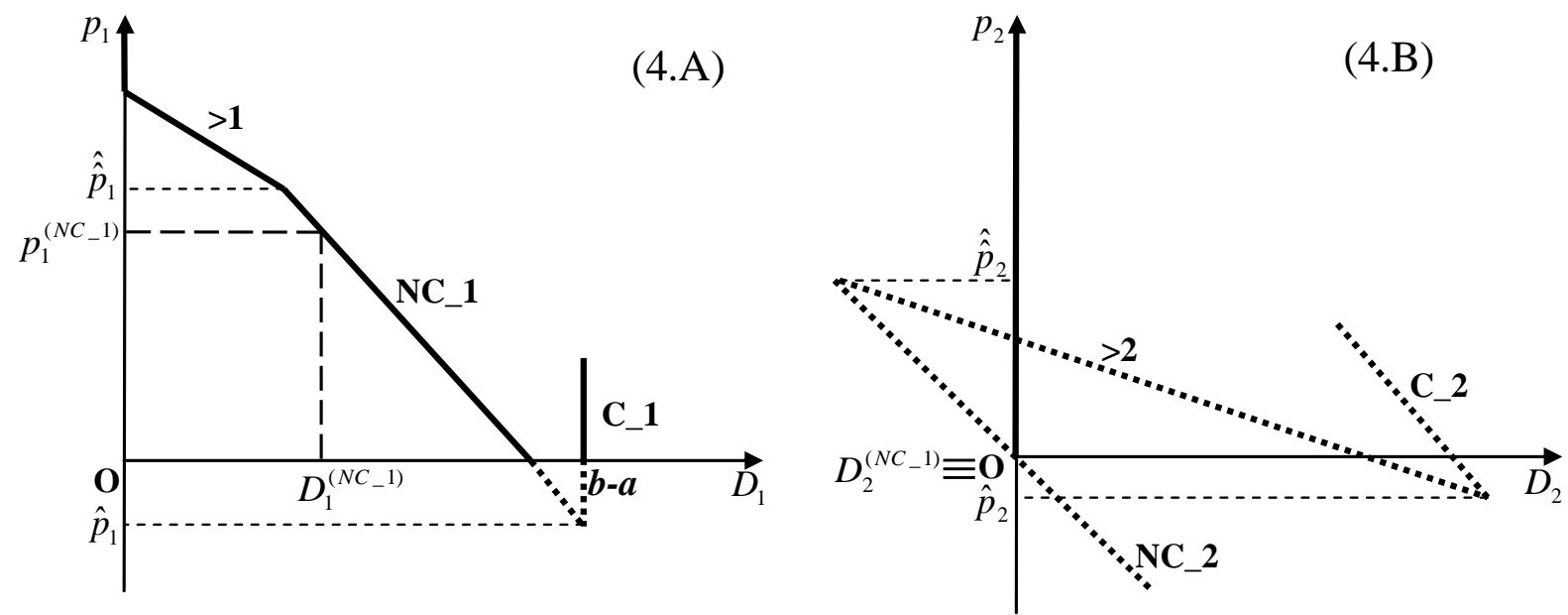

Figure 5: Solution for equilibrium with non-covered monopoly outcome

Panel (5.A) represents the residual demand curve of good with quality rank 1 as given in (18) at a high tax that exceeds the constraint from above 
in (39). The optimal solution is given by the unit-elastic point with coordinates

$\left(D_{1}^{\left(N C_{-} 1\right)}, p_{1}^{\left(N C_{-} 1\right)}\right)$. It belongs to the middle segment $\left(N C_{-} 1\right)$ that is shifted to the left and down so that it has no positive border price $\hat{p}_{1}$ with the bottom segment. As a result, the market is non-covered and no other quality is accommodated in the market. Correspondingly, in Panel (5.B) the optimal solution of a potential second entrant coincides with the origin of the coordination system - it cannot make positive sales even if its good is priced at zero.

\section{Conclusion}

This paper explores the effect that the amount of an exogenous expense can have on the structure and the coveredness of a market for vertically differentiated goods. The exogenous expense is modeled as a lump-sum tax imposed on the incomes of the consumers of the market good.

The results confirm the existence of the covered-duopoly market equilibrium established by Shaked and Sutton (1982) when exogenous expenses are small and tending to zero. At a greater exogenous expense, however, some low-income consumers prefer the outside option. This provides an incentive to the producer of the low-quality good to divert from maximal to minimal product differentiation by choosing the best quality which its individual quality constraint from above allows. In turn, a non-covered duopoly equilibrium can exist at a high exogenous expense. Nonetheless, minimal product differentiation cannot save the positive market share of the low-quality firm if the amount of the exogenous expense exceeds the incomes of all the consumers who prefer the low-quality good to the high-quality good at the equilibrium prices. Such an exogenous expense is unaffordable for these consumers and therefore they choose the outside option instead. Accordingly, a monopoly outcome prevails at equilibrium. 


\section{References}

Brécard, D., (2008), 'Specific versus ad valorem taxation in a differentiated oligopoly,' Université de Nantes, LEN.

Chamberlin, Ed., (1933), Theory of Monopolistic Competition, Harvard University Press, Cambridge.

Constantatos, C., Sartzetakis, E., (1999), 'On commodity taxation in vertically differentiated markets,' International Journal of Industrial Organization, Vol. 17 (8), pp. 1203-1217.

Cremer, H., Thisse, J.-F., (1994), 'Commodity taxation in a differentiated oligopoly,' International Economic Review, Vol. 35 (3), pp. 613-633.

D’Aspremont, C. , Gabszewicz, J.J., Thisse, J.-F., (1979), 'On Hotelling's stability in competition', Econometrica, Vol. 47 (5), pp. 1145-1150.

Gabszewicz, J. and Thisse, J.-F., (1979), 'Price competition, quality and income disparities', Journal of Economic Theory, Vol. 20 (3), pp. 340-359.

Gabszewicz, J. and Thisse, J.-F., (1982), 'Product differentiation with income disparities: an illustrative model', The Journal of Industrial Economics, Vol. 31 (1/2), Symposium on Spatial Competition and the Theory of Differentiated Markets (Sep. - Dec. 1982), pp. 115-129.

Gabszewicz, J. and Thisse, J.-F., (1992), 'Location', in Handbook of Game Theory, edited by R.J.Aumann and S. Hart. Elsevier Science Publishers, Amsterdam, Vol. 1, pp. 281-304. 
Giannakas, K., (2011), 'Consumer demand in vertically differentiated markets', in The Oxford Handbook on the Economics of Food Consumption and Policy, edited by J.Lusk, J. Roosen, J. Shogren, Oxford University Press, Oxford, pp. 243-259.

Hotelling, H., (1929), 'Stability in Competition', Economic Journal, Vol. 39 (153), pp. 41-57.

Loury, G., (1979), 'Market Structure and Innovation', The Quarterly Journal of Economics, Vol. 93 (3), pp. 395-410.

Mussa, M. and Rosen, S., (1978), 'Monopoly and product quality', Journal of Economic Theory, Vol. 18 (2), pp. 301-317.

Rey, P. and Tirole, J., (2007),'A primer on foreclosure,' in Handbook of Industrial Organization, edited by M. Armstrong and R. Porter, Vol. 3, Elsevier North-Holland, Amsterdam, pp. 2145-2220.

Robinson, J., (1934), 'What is perfect competition?', Quarterly Journal of Economics, Vol. 49 (1), pp. 104-120.

Selten, R., (1975), 'Re-examination of the perfectness concept for equilibrium points in extensive games', International Journal of Game Theory, Vol. 4 (1), pp. 25-55.

Shaked, A. and Sutton, J., (1982), 'Relaxing price competition through product differentiation,' The Review of Economic Studies, Vol. 49 (1), pp. 3-13.

Shaked, A. and Sutton, J., (1983), 'Natural oligopolies,' Econometrica, Vol. 51 (1), pp. 1469-1483. 
Tirole, J., (1988), The Theory of Industrial Organization, MIT Press, Cambridge, pp. 1-479.

Wauthy, X., (1996), 'Quality choice in models of vertical differentiation', Journal of Industrial Economics, Vol. 44 (3), pp. 345-353.

Whinston, M., (1990), 'Tying, foreclosure, and exclusion', The American Economic Review, Vol. 80 (4), pp. 837-859. 


\section{Working Paper Series}

ISSN 1211-3298

Registration No. (Ministry of Culture): E 19443

Individual researchers, as well as the on-line and printed versions of the CERGE-EI Working Papers (including their dissemination) were supported from institutional support RVO 67985998 from Economics Institute of the ASCR, v. v. i.

Specific research support and/or other grants the researchers/publications benefited from are acknowledged at the beginning of the Paper.

(c) Georgi Burlakov, 2015

All rights reserved. No part of this publication may be reproduced, stored in a retrieval system or transmitted in any form or by any means, electronic, mechanical or photocopying, recording, or otherwise without the prior permission of the publisher.

Published by

Charles University in Prague, Center for Economic Research and Graduate Education (CERGE) and

Economics Institute of the ASCR, v. v. i. (EI)

CERGE-El, Politických vězňů 7, 11121 Prague 1, tel.: +420 224005 153, Czech Republic.

Printed by CERGE-EI, Prague

Subscription: CERGE-EI homepage: http://www.cerge-ei.cz

Phone: + 420224005153

Email: office@cerge-ei.cz

Web: http://www.cerge-ei.cz

Editor: Marek Kapička

The paper is available online at http://www.cerge-ei.cz/publications/working_papers/.

ISBN 978-80-7343-335-2 (Univerzita Karlova. Centrum pro ekonomický výzkum a doktorské studium)

ISBN 978-80-7344-327-6 (Akademie věd České republiky. Národohospodářský ústav) 
CERGE-EI

P.O.BOX 882

Politických vězňů 7

11121 Praha 1

Czech Republic http://www.cerge-ei.cz 